\title{
BENCHMARKING AS A METHOD OF ADAPTATION OF ORGANIZATIONS TO DYNAMIC BUSINESS CHANGES
}

\author{
Andrea Dobrosavljević, Snežana Urošević \\ Technical Faculty in Bor, University of Belgrade, Serbia \\ Vojske Jugoslavije 12, 19210 Bor, Serbia \\ phone: +381621449984, e-mail: an.dobrosavljevic@gmail.com, surosevic@tfbor.bg.ac.rs
}

\begin{abstract}
Organizations in a modern business environment aim to gain knowledge about best business practice in order to improve performances and to gain competitive advantage on the market. As modern business environment and business opportunities in it can be characterized as turbulent and uncertain, there is an inevitable need for usage of managerial methods and tools that accelerate organization's adaptation to modern business conditions. In order to achieve the desired success it is necessary to introduce the practice that will work on continuous improvement of business. Benchmarking, actually, represents the method for continuous analysis of strategies, functions, processes, products and services, performances and everything else within one organization compared with, compared to "best-in-class" organizations, in order to achieve the best business practice. By using benchmarking organizations are able to manage change more effectively. Literature review included in this paper gives an insight into the latest research papers on benchmarking within change management. Based on it, noticed contributions of the method in in conditions of uncertainty are highlighted and possible directions for further research on this issue are proposed.
\end{abstract}

Keywords: benchmarking, changes, change management, best business practice.

\section{INTRODUCTION}

The modern business environment is becoming more and more dynamic over the years. This reflects on organizations conditioning them to develop so-called "dynamic possibilities", or certain characteristics that, in accordance with the dynamics of the environment, enable the achievement of competitive advantages [1]. Dynamic capabilities allow organizations to create, implement, and protect their intangible resources, which support supreme long-term enterprise performance and provide organization's appropriate response to the rapid change in the environment [2]. Those are physical dynamic capabilities, human and organizational resources that can be used to implement value-creation strategies and include those competencies that are crucial to the company's competitive advantage in modern business conditions [3]. In addition, there is an inevitable need for use managerial methods and tools developed, in order to improve the performance of organizations, and in this paper, special attention is focused on benchmarking method. Organizations must closely monitor environmental changes, then evaluate new technologies, compare with competing organizations, but also with organizations operating within other activities, because by systematic comparison of performance elements of an organization versus those that have developed he best business practice, information which help the company to make the necessary improvements is provided $[4,5]$. They are faced with a constant effort to improve competitiveness in conditions of a changing business environment that has a high degree of uncertainty and risk [6]. Benchmarking is essentially learning how to improve activities, processes and management [7]. It focuses on setting objective standards and performance indicators based on the best practices of those who are best in the class, as well as on the learning how the leading companies achieve their outstanding performance [8]. Change management enables employees to adopt a change so that business objectives are realized. Basically, it represents a bridge between solutions and results [9]. Benchmarking practice helps to manage change by encouraging a culture of continuous improvement [10]. Within IRTIIE Vol. 6, No. 2, 2018 ISSN 1314-8788 (print), ISSN 1314-8796 (online), doi: 10.15547/artte.2018.02.016 


\section{ART'TE $Y$}

Ipplied Researthes in Technics, Technologies and Bduration

Journal of the Faculty of Technics and Technologies, Trakia University https://sites.google.com/a/trakia-uni.bg/artte/

the literature review, presented in this paper, we notice the objects that are necessary for thorough understanding of benefits of use of benchmarking method in conditions of uncertainty and risk and discuss about possible directions of further research and development of solutions on this issue. Therefore, the paper is divided into four units in which it is discussed primarily about understanding of benchmarking, use of benchmarking in change management, benefits of its use and finally conclusions and suggestions for future research.

\section{UNDERSTANDING BENCHMARKING}

Different authors, also different organizations, have given many different definitions of benchmarking, however, all definitions have roots in Robert Camp definition of benchmarking, a Xerox logistics expert and engineer who in 1989. wrote the first descriptive book on benchmarking, "The Search for Industry Best Practices" [11, 12]. As Camp (1992) notes the formal definition of benchmarking is the continuous process of measuring products, services, and practices against the company's toughest competitors or those companies renowned as industry leaders [13]. The benchmarking definition suggests that benchmarking is not just a measurement process that results in a comparative performance measurement, but also describes how remarkable performance is achieved [14]. Moreover, benchmarking helps organizations to identify the gaps in its performance when compared with another organization [15]. Another author, that has paid much attention to this area, Zairi (1998) stresses out that by taking an external perspective to performance through benchmarking, big leaps in performance can be achieved through capturing and adapting or adopting best practice. Benchmarking converts continuous improvement into continuous learning and therefore assists organizations in their pursuit of excellence and superiority in competitiveness [16]. Zairi and Leonard (1994), have proposed the benchmarking evolution over the time where one can clearly see the transition from the reactive nature of the method to adaptation of the method as a part of the business management process, as shown on Figure 1 [17].

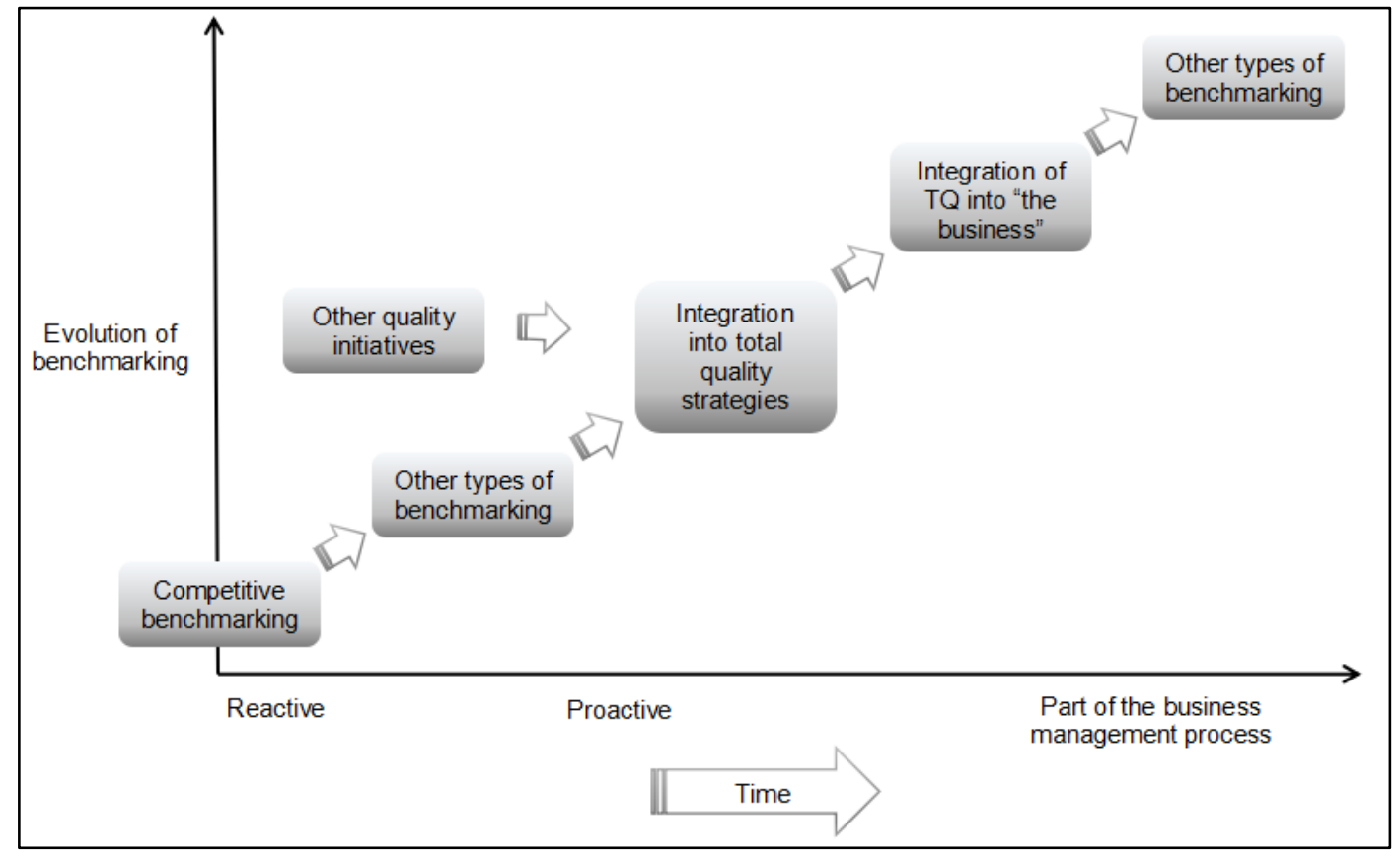

Figure 1. Evolution of benchmarking [17]

IRTIIE Vol. 6, No. 2, 2018 ISSN 1314-8788 (print), ISSN 1314-8796 (online), doi: 10.15547/artte.2018.02.016 


\section{ARTTIE $Y$}

Ipplied Resseirlohes in Technics, Technologies and Bductation

Journal of the Faculty of Technics and Technologies, Trakia University https://sites.google.com/a/trakia-uni.bg/artte/

There are many benchmarking approaches, they vary both in the way the performance assessment models are conceived, and how in practice the methodology is used. Regarding the first aspect, there is an evident trend in developing the model according to the specific characteristics and needs of the benchmarking partners [24]. A recent development has been the move to professionalization in the field of benchmarking, as new benchmarking methodologies have emerged. One such methodology is the TRADE best practice benchmarking methodology. The name of TRADE reminds users to develop strong two-way relationships with the benchmarking partners in order to share or trade information and best practices for mutual benefit [25].

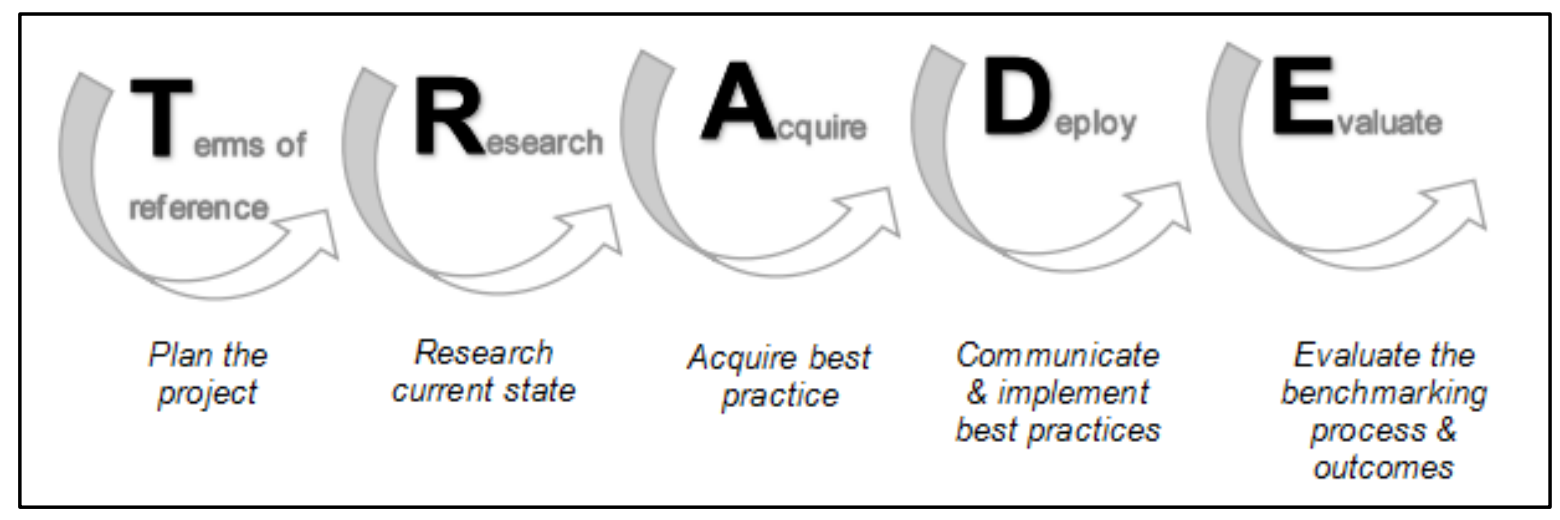

Figure 2. TRADE best practice benchmarking methodology [25]

\section{USE OF BENCHMARKING IN CHANGE MANAGEMENT}

When organizations consider business improvement as a never-ending strategic initiative, they keep themselves at the forefront of change by adopting several tools, like continuous benchmarking, which stop them from having to embark on huge, radical reengineering efforts [26]. Change is an ever-present feature of organizational life, both at an operational and strategic level, so arises the need for a change management as the process of continually renewing an organization's direction, structure, and capabilities to serve the ever-changing needs of external and internal customers [27]. The fact is that we live in a dynamic environment, characterized by a large number of changes, which requires a manager to recognize and anticipate changes in the area it manages and to permanently adapt to them. Managers are oriented towards the future [28]. Benchmarking promotes the climate of change, since benchmarking is being initiated in order to introduce changes in business practice and change the current market position. A gap that is identified between the present and the best practices cause dissatisfaction and desire for change. To make changes successfully, and the transform the company into a competitive company in the market it is necessary to direct the development towards the needs of customers, the development of partnership relations and all that is getting achieved by using new technologies [29]. Spotting, understanding and learning best practice helps in understanding what needs to be changed and how to make changes [30].

In most of cases change management practitioners have attempted to provide solutions to two major problems. First, how to plan better for implementation and second how to overcome employee resistance. However, these two necessary components of change have not produced adequate positive results, especially for transformational changes [31]. Thereby, the concept of organizational readiness for change needs to be mentioned. Organizational readiness for change varies as a function of how much organizational members value the change and how favorably they estimate three key determinants of

IRTIIE Vol. 6, No. 2, 2018 ISSN 1314-8788 (print), ISSN 1314-8796 (online), doi: 10.15547/artte.2018.02.016 


\section{ARTTIE $Y$}

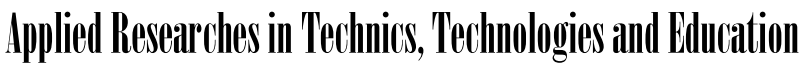

Journal of the Faculty of Technics and Technologies, Trakia University https://sites.google.com/a/trakia-uni.bg/artte/

implementation capability (task demands, resource availability, and situation factors). When organizational readiness for change is high, organizational members are more likely to initiate change, perform greater effort, expose greater persistence, and show more cooperative behavior, which results in more effective change management implementation [32].

Benchmarking is a change management process, and as such has a number of stages that it must pass through to be successful. Along this pathway the following are considered to be some of the key factors that need to be in place to support successful implementation of a benchmarking programme: identifying the drivers for change; identifying the key processes and variables that influence performance (the critical success factors); having support from the top, including senior management and politicians; having dynamic management which seeks to enhance scheme performance; having a socio-political environment in which change is feasible, and even demanded, by key stakeholders; developing a sense of ownership by key stakeholders of the change processes identified as being necessary to enhance performance; identifying key stakeholders who can block the change process and finding ways to overcome their resistance; allowing sufficient time and resources to identify indicators, collect and analyse data, and share data and discuss and agree options for change with key stakeholders [33].

\section{BENEFITS FROM THE USE OF BENCHMARKING}

The concept of change is an integral part of benchmarking, however, while every improvement means the change, not every change means improvement [34]. As one of the benefits of use, here can be considered the fact that benchmarking is not just seeking to make changes, but its main objective is to add value to the organization [15]. Among the main advantages of benchmarking use, some of the following can be mentioned. Strong incentives are provided for to operators to be efficient and innovative, minimizing the costs of operation and capital expenditures, a fairer recovery of costs and of capital investments is assured, an on-going pressure is put to improve product and service quality which also leads to increase in customers satisfaction. More benefits are, opening new business opportunities, achieving the maximum in business, achieving competitive advantages and improving the quality of the entire organization and gaining the profit. What is also important is that it comes to an increase in transparency and sharing of information, minimizing its asymmetry between different stakeholders [35, 36].

As the authors Bhutta and Huq (1999) state, benchmarking cannot be carried out in isolation and has to match and contribute to the overall business objectives of the organization to be of benefit [37].To be very successful in benchmarking a combination of commitment, critical self-analysis and discipline at key steps in the process are essential [38]. The use of benchmarking in practice is not an easy task because for example, the selection of processes as the object of benchmarking analysis requires knowledge of their progress and assessment of their impact on the performance of the organization [39].

In addition to the advantages of using this method in practice, there are certain disadvantages. Defining 'best practice' is no easy matter. Data have to be collected and collated in comparable terms, and where benchmarking is cooperative, reaching agreement on the most appropriate bases can be difficult, especially if it involves significant changes to existing reporting arrangements [40]. As a weakness of benchmarking can also be considered the fact that it does not necessarily mean that the best practice practice of an organization can produce similar results in the other. A variety of factors, such as corporate culture, history, markets, structure, leadership, or business model, among other things, can prevent achievement of desired results. Benchmarking is therefore particularly important not to copy the best practice on your business process, but to adapt it in order to make it

IRTIIE Vol. 6, No. 2, 2018 ISSN 1314-8788 (print), ISSN 1314-8796 (online), doi: 10.15547/artte.2018.02.016 


\section{ART'TE

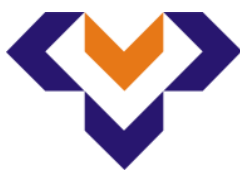 \\ Ipplied Researthes in Technics, Technologies and Bduration \\ Journal of the Faculty of Technics and Technologies, Trakia University https://sites.google.com/a/trakia-uni.bg/artte/}

uniquely adjusted to the organization [41].

Specific benchmarking applications and benchmarking cases can be considered to provide insight into the growth of the benchmarking concept since its launch in 1989 by the Xerox Company, as it is often quoted in the literature [42]. Efficient and frequent use of benchmarking is noticeable in the field of project management, where also exists the high level of uncertainty and risk. Zwikael and Globerson (2006) make comparisons between different industries in order to identify the industry in which the projects are best implemented and planned. The identified industry is then used as a standard for improvements in project planning within other industries. This research was conducted on the basis of data collected from 280 project managers, and was evaluated the success and quality of project planning. It included four industries in Israel and Japan, more precisely construction and engineering, software and communications, services and production and maintenance. The results indicated that the quality of project planning is at the highest level in construction and engineering and at the lowest level in production organizations [43]. In terms of selection the appropriate benchmark or carrier of good practice Bojković et al. (2014) suggest as a solution the stepwise benchmarking concept. Basically, instead of choosing one, the best, model, idea is to identify the set of appropriate bearers of good practice. In this way, the organization can define an evolutionary development path or strategy, which will, in a proper dynamic, bring the performances of that organization to the highest level [44]. Yakovleva et al. (2012), in their paper provide more findings about benefits which can be achieved by the use of benchmarking. They developed a benchmarking framework using real world data and expert opinion for the food supply chain. The results have shown that if applied to a company level, the developed benchmarking framework could assist consumers to evaluate sustainability performance of equivalent product lines and form their purchasing behavior. Thus, strategic, tactical and operational considerations for a variety of stakeholders can be evaluated with the results of this sustainability methodology [45]. Beyer et al. (2015) in the paper "Benchmarking and Resource Management: Application to Automatic Verification" set the goal to establish a technological foundation for performance evaluation of verification tools that is based on modern technology and makes it possible to measure and control resources in an accurate, reliable, and reproducible way in order to obtain scientifically valid experimental data [46]. Kos et al. (2015) stresses out that big data processing and big data applications are shifting the computing paradigms, computing concepts, and treatment of data. Also, that managing big data is a many-sided problem. Their research resulted in presentation of a new benchmarking methodology based on a measure $M$ defined as the number of unit size computers required to achieve the projected execution. Benefit derived from this research is that by using the new methodology data flow computers would outrank the control flow computers on a top 500 list for a number of big data applications [47].

\section{CONCLUSION}

In modern dynamic business environment, environment of fast changes and great competition, exists great need for development of such business policy that will not only assure current success, but also, bring long term results. In this paper, the greatest attention is focused on understanding the concept of benchmarking and its place within change management. For that purpose, were examined theoretical findings and practical research from this field. Review of latest research has shown new directions of benchmarking methodology development, towards modernization and popularization of methodology. However, the question how the benefits of use of benchmarking method might be better achieved still arises. Further research should include considering the solutions for successful implementation of benchmarking methodology while minimizing the disadvantages of using this method.

IRTIIE Vol. 6, No. 2, 2018 ISSN 1314-8788 (print), ISSN 1314-8796 (online), doi: 10.15547/artte.2018.02.016 


\section{ARTITE $Y$}

Ipplied Resseirlohes in Technics, Technologies and Bductation

Journal of the Faculty of Technics and Technologies, Trakia University https://sites.google.com/a/trakia-uni.bg/artte/

\section{REFERENCES}

[1] Teece, D., Pisano, G. (1994). The dynamic capabilities of firms: an introduction, Industrial and corporate change, 3 (3), 537-556.

[2] Teece, D. J. (2007). Explicating dynamic capabilities: the nature and microfoundations of (sustainable) enterprise performance, Strategic management journal, Vol. 28 (13), 13191350.

[3] Eisenhardt, K. M., \& Martin, J. A. (2000). Dynamic capabilities: what are they?, Strategic management journal, Vol. 21, 1105-1121.

[4] Babić, J. (2011). Značaj primene međunarodnih ISO standarda za upravljanje preduzećem i obezbeđivanje satisfakcije potrošača, Marketing, 180-188.

[5] Choy, K. L., Lee, W. B., Lo, V. (2002). An intelligent supplier management tool for benchmarking suppliers in outsource manufacturing, Expert Systems with Applications, 22, 213-224

[6] Arsić, M., Urošević, S. (2009). Reinženjering i unapređenje kvaliteta poslovanja domaćih preduzeća, V Majska konferencija o strategijskom menadžmentu, Univerzitet u Beogradu, Tehnički fakultet u Boru, ISBN 978-86-80987-67-5, Zaječar, 29-31.05.2009, Zbornik radova, 232-241.

[7] Kyrö, P. (2003). Revising the concept and forms of benchmarking, Benchmarking: An International Journal, Vol. 10, No. 3, pp. 210-225.

[8] Pemberton, J., Stonehouse, G., Yarrow, D. (2001). Benchmarking and the role of organisational learning in developing competitive advantage, Knowledge and Process Management, Volume 8, Number 2, pp. 123-135.

[9] Hiatt, J., Creasey, T. J. (2003). Change management: The people side of change, Prosci Learning Center Publications.

[10] Barber, E. (2004). Benchmarking the management of projects: a review of current thinking, International Journal of Project Management, 22, 301-307.

[11] Abbas, A. (2014). The Characteristics of Succesfull Benchmarking Implementation, Guidlines for a national strategy for promoting benchmarking, Massey University, Manawatu, New Zealand.

[12] Dole, W. V. (2016). Benchmarking: The search for peers. A hybrid library's experience, Journal of Library Administration, 56 (8), 1018-1029.

[13] Camp, R. (1992). Learning from the Best Leads to Superior Performance, Journal of Business Strategy, Vol. 13, Issue: 3, pp. 3-6.

[14] Ajelabi, I., Tang, Y. (2010). The Adoption of Benchmarking Principles for Project Management Performance Improvement, International Journal of Managing Public Sector Information and Communication Technologies (IJMPICT), Vol. 1, No. 2.

[15] Alosani, M. S., Al-Dhaafri, H. S., Yusoff, R. Z. B. (2016). Mechanism of Benchmarking and Its Impact on Organizational Performance, International Journal of Business and Management, 11 (10), 172.

[16] Zairi, M. (1998). Benchmarking for Best Practice: Continuous Learning Through Sustainable Innovation, Routledge.

[17] Zairi, M., Leonard, P. (1994). Practical Benchmarking: The Complete Guide: A complete guide, Springer Science \& Business Media.

[18] Passos, C., Haddad, R. (2013). Benchmarking: A tool for improvement of production management, $6^{\text {th }}$ IFAC Conference on Management and Control of Production and Logistics, September 11-13, Fortaleza, Brazil.

[19] Nazarko, J., Kuźmicz, K. A., Szubzda - Prutis, E., Urban, J. (2009). The general conept of benchmarking and its application in higher education in Europe, Higher Education in Europe, Vol. 34, No. 3\&4, pp. 497-510. 


\section{IRTITIE}

Ipplied Resseirlohes in Technics, Technologies and Bductation Journal of the Faculty of Technics and Technologies, Trakia University https://sites.google.com/a/trakia-uni.bg/artte/

[20] Mellat Parast, M., Adams, S. (2012). Corporate social responsibility, benchmarking, and organizational performance in petroleum industry: A quality management perspective, Int. J. Production Economics, 139, 447-458.

[21] Shen, Q., Liu, G. (2007). The selection of benchmarking partners for value management: an analytic approach, International Journal of Construction Management, 7 (2), 11-22.

[22] Zairi, M., Youssef, M. (1995). A review of key publications on benchmarking part I, Benchmarking for Quality Management \& Technology, 2 (1), 65-72.

[23] Cooper, K., \& Shumate, M. (2015). Sharing data in collective impact efforts, Stanford Social Innovation Review.

[24] Ribeiro, L. M., \& Sarsfield Cabral, J. A. (2006). A benchmarking methodology for metalcasting industry, Benchmarking: An International Journal, 13 (1/2), 23-35.

[25] Mann, R. (2015). Expert point of view note the history of benchmarking and its role in inspiration, Journal of Inspiration Economy, 2 (2), 131-143.

[26] Al-Mashari, M., Irani, Z., Zairi, M. (2001). Business process reengineering: a survey of international experience, Business Process Management Journal, Vol. 7, No. 5, pp. 437 455.

[27] Todnem By, R. (2005). Organisational change management: A critical review, Journal of change management, 5 (4), 369-380.

[28] Urošević, S., Arsić, M. (2009) "Uloga i funkcije menadžera u savremenim uslovima poslovanja", V Majska konferencija o strategijskom menadžmentu, Univerzitet u Beogradu, Tehnički fakultet u Boru, ISBN 978-86-80987-67-5, Zaječar, 29-31.05.2009., Zbornik radova, 394-402.

[29] Urošević, S., Riznić, D. (2009). "Improving of Business and Acquiring the Concurrence Advantage by using the re-engineering of Business Processes in Domestic Companies", 9th International Conference., "Research and Development in Mechanical Industry“ RaDMI 2009 16-19. September 2009. Vrnjačka Banja, Serbia, ISBN 978-86-6075-008-4, Volume 2, 950-955.

[30] Codling, S. (1992). Best Practice Benchmarking: A Management Guide, Gower Publishing, Ltd.

[31] Anderson, D., Anderson, L. A. (2010). Beyond change management: How to achieve breakthrough results through conscious change leadership, Vol. 36, John Wiley \& Sons.

[32] Weiner, B. J. (2009). A theory of organizational readiness for change, Implementation science, $4(1), 67$.

[33] Malano, H., Burton, M., Makin, I. (2004). Benchmarking performance in the irrigation and drainage sector: a tool for change, Irrigation and drainage, 53 (2), 119-133.

[34] Moriarty, J., Smallman, C. (2009). En route to theory of benchmarking, Benchmarking: An International Journal Vol 16, No. 4, pp.484-503.

[35] Marques, R. C., Simões, P., Pires, J. S. (2011). Performance benchmarking in utility regulation: the worldwide experience, Polish Journal of Environmental Studies, 20 (1), 125-132.

[36] Đuričić, Z., Jovanović, K., Đuričić, R. (2010). Benchmarking kao instrument savremenog menadžmenta. In International Scientific Conference MANAGEMENT 2010, Kruševac, Srbija, 17-18 March 2010.

[37] Bhutta, K. S., Huq, F. (1999). Benchmarking-best practices: an integrated approach, Benchmarking: An International Journal, 6 (3), 254-268.

[38] Rolstadås, A. (2013). Benchmarking - Theory and Practice, Springer.

[39] Walas-Trębacz, J. (2015). Management instruments used for the improvement of the enterprise value chain in order to increase its competitiveness. Ekonomika, 61 (2), 3953.

[40] Arrowsmith, J., Sisson, K., Marginson, P. (2004). What can 'benchmarking'offer the open method of co-ordination?, Journal of European Public Policy, 11 (2), 311-328.

IRITIE Vol. 6, No. 2, 2018 ISSN 1314-8788 (print), ISSN 1314-8796 (online), doi: 10.15547/artte.2018.02.016 


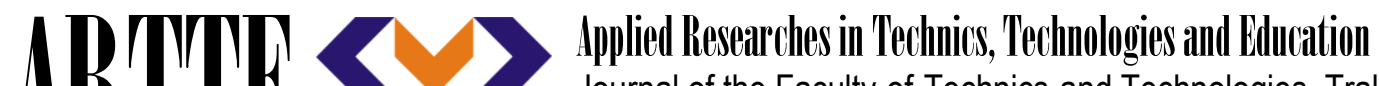 Journal of the Faculty of Technics and Technologies, Trakia University https://sites.google.com/a/trakia-uni.bg/artte/}

[41] Fleisher, C., Bensoussan, B. (2015). Business and Competitive Analysis: Effective Application of New and Classic Methods, FT Press.

[42] Dattakumar, R., Jagadeesh, R. (2003). A review of literature on benchmarking, Bencmarking: An International Journal, Vol. 10, No. 3, pp. 176-209.

[43] Zwikael, O., Globerson, S. (2006). Benchmarking of project planning and success in selected industries, Benchmarking: An International Journal, 13 (6), pp. 688-700.

[44] Bojković, N., Petrović, M., Parezanović, T. (2014). Indikatori ključnih performansi za benčmarking ekološke održivosti u sektoru informaciono-komunikacionih tehnologija, XXXII Simpozijum o novim tehnologijama u poštanskom i telekomunikacionom saobraćaju, PosTel 2014, Beograd 2. i 3. decembar 2014.

[45] Yakovleva, N., Sarkis, J., Sloan, T. (2012). Sustainable benchmarking of supply chains: the case of the food industry, International journal of production research, 50 (5), 12971317.

[46] Beyer, D., Löwe, S., \& Wendler, P. (2015). Benchmarking and resource measurement, In Model Checking Software (pp. 160-178). Springer, Cham.

[47] Kos, A., Tomažič, S., Salom, J., Trifunovic, N., Valero, M., Milutinovic, V. (2015). New benchmarking methodology and programming model for big data processing, International Journal of Distributed Sensor Networks, 11 (8), 271752. 